\title{
Algal flora of Betana wetland, Morang, Nepal
}

\author{
Shiva Kumar Rai \\ Department of Botany, P.G. Campus, Tribhuvan University, Biratnagar, Nepal \\ E-mail: shivarai2003@yahoo.com
}

\begin{abstract}
In this paper, a total 23 epiphytic as well as planktonic taxa belonging to the classes cyanophyceae (6), chlorophyceae (1) and bacillariophyceae (16) have been enumerated from Betana wetland. Out of these, six diatom taxa viz., Gomphonema constrictum Ehr. var. capitata, Gomphonema intricatum Kütz. var. vibrio, Gomphonema parvulum (Kütz.) var. lagenula Hust., Rhopalodia gibba (Ehr.) O. Müll. var. ventricosa, Nitzschia amphibia Grun. and Surirella tenera Greg. var. ambigua Gandhi were the new records for the country.
\end{abstract}

Key words: Algae, Betana, Diatoms, Nepal.

\section{Introduction}

Betana wetland is a freshwater ox-bow pond situated between $26^{\circ} 39^{\prime} 47.8^{\prime \prime} \mathrm{N}$ to $87^{\circ} 26^{\prime} 02.8^{\prime \prime} \mathrm{E}$ and $26^{\circ} 39^{\prime} 33.5^{\prime \prime} \mathrm{N}$ to $87^{\circ} 26^{\prime} 02.9^{\prime \prime} \mathrm{E}$ at an elevation of $123 \mathrm{~m} \mathrm{msl}$, covering ca 5.5 ha area in Belbari VDC, Morang (Map 1). The pond is surrounded by Sal forest of Char-Koshe-Jhadi from east, north and west sides whereas Mahendra Rajmarg lies adjacent on its south. The sources of its water are the water released from the surrounding forest and atmospheric precipitation. From its edge to the centre, water depth varies from 0.5 to $1.5 \mathrm{~m}$ in dry season and 1 to $2.5 \mathrm{~m}$ in monsoon season (Jha et al., 2005). Generally, in rainy season when water level raises, over-water drained out through artificial outlets constructed at its southern bank. The area experiences tropical monsoonic climate having three distinct viz., winter (November-February), summer (March-June) and rainy (July-October) seasons in a year. Soil is alluvial type and the meteorological records are: average annual rainfall $1312 \mathrm{~mm}$, average annual minimum and maximum temperatures $14.2^{\circ} \mathrm{C}$ and $30.6^{\circ} \mathrm{C}$ respectively.

The common macrophytes of this pond are Azolla imbricata, Blyxa japonica, Ceratophyllum demersum, Eichhornia crassipes, Hydrilla verticillata, Ipomoea carnea, Pistia stratioites and Potamogeton crispus.

Phycological explorations in eastern Nepal have been carried out by various workers viz.,

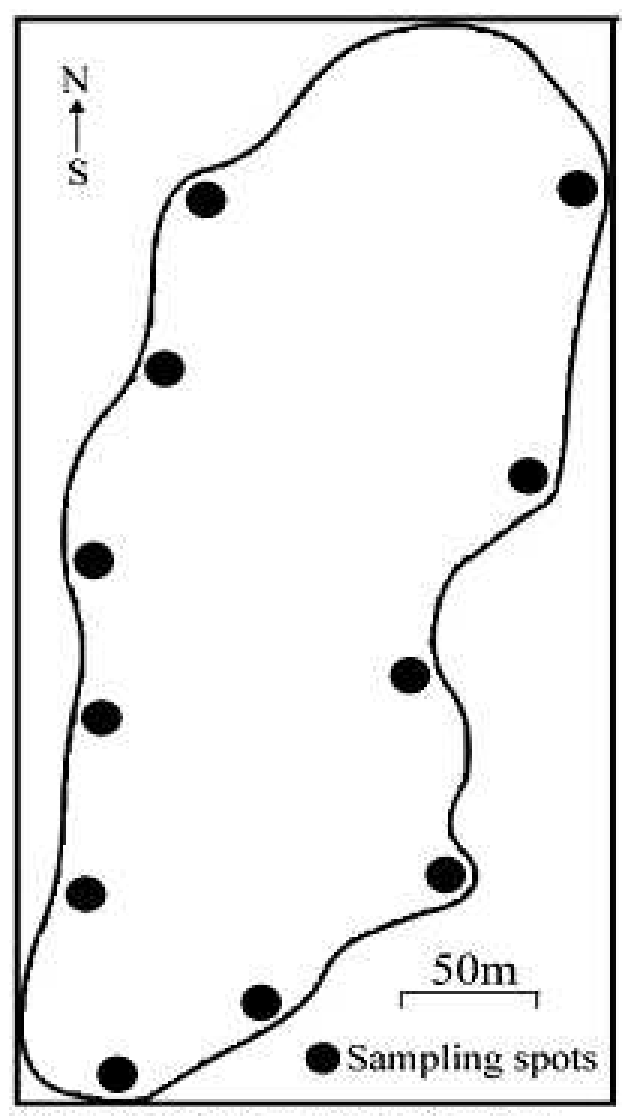

Map 1. Betara wetland showing algal collection sites. 
Rai (2005, 2006, 2009), Rai and Rai (2005, 2007), Rai and Misra (2007, 2008), Rai et al. (2008 a, 2008 b, 2010), Misra et al. (2009) and Subba et al. (2009). Only five algal species viz., Lyngbya birgei, Lyngbya majuscule, Nostochopsis lobatus, Fragilaria construence var. construence and Eunotia tschirchiana have been reported from this wetland before (Rai \& Misra, 2010).

\section{Materials and Methods}

Planktonic forms were collected with the help of mesh net (pore size $5 \mu \mathrm{m}$ ) whereas epiphytic forms by squeezing submerged macrophytes, from 11 peripheral spots of the wetland (Map 1). Few algae especially diatoms were also collected by brushing the slimy surface of the pebbles. All the samples were preserved in $4 \%$ (final concentration) formaldehyde solution. Further study viz. measurement, identification, microphotograpy etc. were carried out in the laboratory, Department of Botany, P.G. Campus, Biratnagar. For better viewing and identification, diatom frustules were washed with saturated solution of chromic acid (potassium dichromate dissolved in conc. $\mathrm{H}_{2} \mathrm{SO}_{4}$ ). The slides thus prepared were observed and took microphotography using Carl Zeiss Axioster plus microscope and Canon digital camera (8 mega pixel). Taxonomic identification have been made up to the species and variety level following standard literature and monographs viz., Geitler (1932), Deshikachary (1959), Prasad and Srivastava (1992), Rai et al. (2010), Rai and Misra (2010) etc.

\section{Taxonomic Description}

\section{Cyanophyceae}

1. Merismopedia elegans A. Braun in Kützing (Fig. 1)

Desikachary 1959, p. 156, pl. 29, fig. 9; Rath \& Adhikary 2005, p. 44, pl. 6, fig. 3; pl. 15, fig. 110.

Whole colony $98.7 \mu \mathrm{m}$ long, $78.5 \mu \mathrm{m}$ broad; cells $8.2 \mu \mathrm{m}$ long, $5.8 \mu \mathrm{m}$ broad.

Distribution in Nepal: Phewa lake, 967 m, Pokhara, Kaski (Ishida, 1986); Chandi river, Chandranigahpur and Rapti river, Hetauda (Sahay et al., 1993); Lamphengwa, Pheyong and Deumai rivers, Gajurmukhi, Ilam (Rai et al., 2008a); Paddy field and damp soil around a tap, Hongchur, 850 m, Khotang (Rai \& Misra, 2010).

2. Oscillatoria princeps Vauch. ex Gom. (Fig. 2)

Desikachary 1959, p. 210, pl. 37, figs. 1, 10-11, 13-14; Sant'anna \& Azevedo 1995, p. 42, fig. 88.

Trichomes 28.5-38 $\mu \mathrm{m}$ broad; cells 5-5.5 $\mu \mathrm{m}$ long.

Distribution in Nepal: A pond at Patan Dhoka, 1,300 m, Lalitpur (Hirano, 1963); Narayani river, Narayanghat, Chitwan (Upadhyaya, 1979); Kara river at Hetauda and Malangwa (Sahay et al., 1993); Main dam of Khageri Khola at Tikauli, Chitwan, and Jayshree Khola at Gaindakot, Nawalparasi (Das \& Verma, 1996); Paddy and Sugarcane field, Birganj, Parsa (Prasad, 1996); Roadside pools, Mahendranagar, Kanchanpur (Habib, 1997); Kusaha, Haripur, and Madhubani of Sunsari, Eastern Nepal (Jha \& Kargupta, 2001); Malaya roadside ditches, 72 m, Biratnagar (Rai \& Misra, 2010).

3. Lyngbya birgei G.M. Smith (Fig. 3)

Desikachary 1959, p. 296, pl. 50, figs. 7-8; Prasad \& Srivastava 1992, p. 89, pl. 10, fig. 9. 
Filaments 22-25.5 $\mu \mathrm{m}$ broad; sheath 1-1.6 $\mu \mathrm{m}$ thick; trichomes $19-20.5 \mu \mathrm{m}$ broad; cells 3.5-4 $\mu \mathrm{m}$ long.

Remarks: The present specimen has slightly longer cells.

Distribution in Nepal: Sundarijal, 1,300 m, Kathmandu; Patan, 1,300 m, Lalitpur; Thimi, 1,300 m, Bhaktapur (Shrestha, 1982; Shrestha \& Manandhar, 1983); Betana wetland, Morang (Rai \& Misra, 2010).

4. Lyngbya majuscula (Dillwyn) Harv. ex Gom. (Fig. 4)

Desikachary 1959 , p. 313 , pl. 48, fig. 7; pl. 49, fig. 12; pl. 52, fig. 10; Prasad \& Srivastava 1992, p. 93, pl. 11, fig. 2.

Filaments 13.5-16 $\mu \mathrm{m}$ broad; sheath 1.4-3.2 $\mu \mathrm{m}$ thick; trichomes $10.5-11.4 \mu \mathrm{m}$ broad; cells 2.3-3 $\mu \mathrm{m}$ long.

Distribution in Nepal: Betana wetland, Morang (Rai \& Misra, 2010)

5. Anabaena iyengarii Bharadwaja (Fig. 5)

Desikachary 1959, p. 406, pl. 78, fig. 2.

Trichomes $6 \mu \mathrm{m}$ broad; heterocysts $9.5 \mu \mathrm{m}$ long, $7.5 \mu \mathrm{m}$ broad; akinets $15-25 \mu \mathrm{m}$ long, 8-11 $\mu \mathrm{m}$ broad.

Distribution in Nepal: Chandi river at Chandranigahpur (Sahay et al., 1993); a pond near Sharada dam, Mahendranagar, Kanchanpur (Habib, 1997); Kusaha and Haripur of Sunsari, Eastern Nepal (Jha \& Kargupta, 2001); Titrigachi pond, Koshi Tappu, Kusaha, 206 m, Sunsari (Rai \& Misra, 2010).

6. Nostochopsis lobatus Wood em. Geitler (Fig. 6)

Geitler 1932, p. 475, figs. 28, 285-286; Desikachary 1959, p. 570, pl. 120, figs. 1-8.

Thallus up to $4 \mathrm{~cm}$ in diameter; cells $4-10 \mu \mathrm{m}$ long, up to $5 \mu \mathrm{m}$ broad; heterocysts 6 $7.5 \mu \mathrm{m}$ long, 5.5-6.5 $\mu \mathrm{m}$ broad.

Distribution in Nepal: A pond at Godawari, 1,400 m, Lalitpur (Shrestha, 1982; Shrestha \& Manandhar, 1983; Watanabe \& Komarek, 1988); Betana wetland, Morang (Rai \& Misra, 2010).

\section{Chlorophyceae}

7. Cosmarium maculatiforme Schm. (Fig. 7)

Turner 1892, P. 49, pl. 8, fig. 68 (as C. maculatum forma); Nurul Islam 1970, p. 924, pl. 14, fig. 1.

Cells $120 \mu \mathrm{m}$ long, $62.5 \mu \mathrm{m}$ broad; isthmus $42.5-45 \mu \mathrm{m}$ wide.

Distribution in Nepal: Variety maior reported from a pond at Luitel Bhanjyang, $770 \mathrm{~m}$, Gorkha (Hirano, 1955); Bees hazaar lake, Chitwan (Rai et al., 2008b).

\section{Bacillariophyceae}

8. Melosira varians Ag. (Fig. 8)

Hadi et al. 1984, p. 518, pl. 1, fig. 21; pl. 8, fig. 131; Sinnu \& Squires 1985, p. 298, pl. 1, fig. 1 .

Frustule $15 \mu \mathrm{m}$ in diameter; semicell $12 \mu \mathrm{m}$ high.

Distribution in Nepal: A pond at Ankhu Khola, $640 \mathrm{~m}$ and Luitel Bhanjyang, $770 \mathrm{~m}$, Gorkha (Hirano, 1955); Pitchhra pond, 72 m, Biratnagar (Rai \& Rai, 2005); Lamphengwa, Pheyong and Deumai rivers, Gajurmukhi, Ilam (Rai et al., 2008a); Muga river, 1850 m, Pakhribas, Dhankuta; Hongchur river, 900 m, Khotang; Chimdi lake, 73 m, Sunsari (Misra et al., 2009). 
9. Fragilaria construence (Ehr.) Grun. var. construence (Fig. 9)

Kobayasi 1968, p. 96, pl. 1, figs. 10-11; Foged 1982, p. 350, pl. 1, fig. 9; pl. 4, fig. 10 (as Fragilaria construence).

Valves $14 \mu \mathrm{m}$ long, $5 \mu \mathrm{m}$ broad; girdles $14 \mu \mathrm{m}$ long, $4.9 \mu \mathrm{m}$ broad.

Distribution in Nepal: Betana wetland, 123 m, Belbari, Morang (Misra et al., 2009).

10. Eunotia tschirchiana Müll. (Fig. 11)

Hustedt 1938, p. 173-174, pl. 12, fig. 29; Gandhi 1999, p. 26, pl. 1, fig. 37; p. 92, pl. 1, fig. 23; p. 153, pl. 2, fig. 61 .

Valves 53-62.5 $\mu \mathrm{m}$ long, 8.5-10 $\mu \mathrm{m}$ broad; striae 8-13 in $10 \mu \mathrm{m}$.

Distribution in Nepal: A stream at Mewa valley, Eastern Nepal (Hirano, 1984); Muga river, 1850 m, Pakhribas, Dhankuta; Pond inside Birendra Sabha Griha compound, 72 m, Biratnagar, Morang; Betana wetland, 123 m, Belbari, Morang (Misra et al., 2009).

11. Cocconeis placentula Ehr. var. euglypta (Ehr.) Cl. (Fig. 14)

Hadi et al. 1984, p. 526, pl. 9, fig. 158; Sinnu \& Sqires 1985, p. 301, pl. 5, figs. 37-40. Valves $35.5 \mu \mathrm{m}$ long, $19.5 \mu \mathrm{m}$ broad; striae $18-19$ in $10 \mu \mathrm{m}$.

Distribution in Nepal: Rawa Khola (river), 720 m, Manglabare, Khotang (Misra et al., 2009).

12. Navicula viridula (Kütz.) Ehr. (Fig. 21)

Tiffany \& Britton 1952, p. 255, pl. 67, fig. 785; Gandhi 1999, p. 54, pl. 3, fig. 124. Valves 56.5-77 $\mu \mathrm{m}$ long, 13-15 $\mu \mathrm{m}$ broad; striae 6-7 (middle) to 9-10 (pole) in $10 \mu \mathrm{m}$. Distribution in Nepal: A pond at Ankhukhola, Gorkha, 640 m. (Hirano, 1955); Punyamati river, Kavrepalanchowk (Aryal \& Lacoul, 1996); Kathmandu, Likhu khola and Arun valley (Jüttner et al., 1996).

13. Stauroneis javanica (Grun.) Cl. (Fig. 10)

Hustedt 1959, p. 813-817, fig. 1159.

Valves $98 \mu \mathrm{m}$ long, $20.5 \mu \mathrm{m}$ broad.

Distribution in Nepal: S. javanica (Grun.) Cl. var. oblonga Ostr. was reported from a stream at Mewa valley, eastern Nepal (Hirano, 1984).

14. Pinnularia braunii (Grun.) Cl. var. amphicephala (A. Mayer) Hust. (Fig. 12)

Foged 1980, p. 660, pl. 8, fig. 8; Prasad \& Srivastava 1992, p. 230, pl. 30, fig. 13.

Valves 47.5-58 $\mu \mathrm{m}$ long, 9.5-10.5 $\mu \mathrm{m}$ broad; striae 10-12 in $10 \mu \mathrm{m}$.

Distribution in Nepal: A stream at Mewa valley, Eastern Nepal (Hirano, 1984);

Sarouchia pond, 72 m, Biratnagar (Rai \& Rai, 2005); Lamphengwa, Pheyong and Deumai rivers, Gajurmukhi, Ilam (Rai et al., 2008a).

15. Gyrosigma scalproides (Rabenh.) Cl. (Fig. 19)

Tiffany \& Britton 1952, p. 269, pl. 66, fig. 762; Prasad \& Srivastava 1992, p. 241, pl. 31, fig. 9 .

Valves $52 \mu \mathrm{m}$ long, $8.5 \mu \mathrm{m}$ broad; transverse striae 24 in $10 \mu \mathrm{m}$.

Distribution in Nepal: Kathmandu valley, Likhu Khola, and Arun valley (Eastern Nepal) (Juettner et al., 1996).

16. Gomphonema cf. constrictum Ehr. var capitata (Ehr.) Cl. (Fig. 16)

Tiffany \& Britton 1952, p. 271, pl. 72, fig. 840; Foged 1986, p. 562, pl. 6, figs. $7 \& 12$.

Valves $39 \mu \mathrm{m}$ long, $10.5 \mu \mathrm{m}$ broad; transverse striae 11 in $10 \mu \mathrm{m}$.

Distribution in Nepal: New record for Nepal.

17. Gomphonema cf. intricatum Kütz.var. vibrio (Ehr.) Cl. (Fig. 20)

Tiffany \& Britton 1952, p. 271, pl. 72, fig. 837; Gandhi 1959, p. 325, fig. 46.

Valves $99.5 \mu \mathrm{m}$ long, $10.5 \mu \mathrm{m}$ broad; transverse striae $7-8$ in $10 \mu \mathrm{m}$. 
Distribution in Nepal: New record for Nepal.

18. Gomphonema cf. parvulum (Kütz.) var. lagenula Hust. (Fig. 17)

Carter \& Denny 1987, p. 244, pl. 3, fig. 7.

Valves $52 \mu \mathrm{m}$ long, $16 \mu \mathrm{m}$ broad; auger shaped, transverse striae 9-11 in $10 \mu \mathrm{m}$.

Distribution in Nepal: New record for Nepal.

19. Gomphonema sphaerophorum Ehr. (Fig. 15)

Tiffany \& Britton 1952, p. 272, pl. 72, fig. 847; Prasad \& Srivastava 1992, p. 257, pl. 33, fig. 10.

Valves $43.5 \mu \mathrm{m}$ long, $9 \mu \mathrm{m}$ broad; striae $10-12$ in $10 \mu \mathrm{m}$.

Distribution in Nepal: A pond near Phewa lake, 967 m, Pokhara, Kaski (Hirano, 1955);

a pond near Police Station, Mahendranagar, Kanchanpur (Habib, 1997); Triyuga river, 152 m, Udayapur (Rai, 2006).

20. Cymbella cymbiformis (Ag.) Kütz. var. nonpunctata Font. (Fig. 13)

Hadi et al. 1984, p. 534, pl. 5, fig. 75; pl. 11, fig. 193.

Valves $63.5 \mu \mathrm{m}$ long, $12.5 \mu \mathrm{m}$ broad; striae 9 in $10 \mu \mathrm{m}$.

Distribution in Nepal: A stream at Kungbachen, 4150 m. (Hirano, 1984)

21. Rhopalodia gibba (Ehr.) O. Müll. var. ventricosa (Ehr.) Grun. (Fig. 22)

Foged 1980, p. 661, pl. 11, figs. 2-4; Gandhi 1999, p. 229, pl. 8, fig. 293.

Valves 65-91 $\mu \mathrm{m}$ long, 10-16 $\mu \mathrm{m}$ broad; costae $1-4$ in $10 \mu \mathrm{m}$; striae 9 in $10 \mu \mathrm{m}, 2-9$ stroae between two costae.

Distribution in Nepal: New record for Nepal.

22. Nitzschia amphibia Grun. (Fig. 18)

Prasad \& Srivastava 1992, p. 285, pl. 36, fig. 16; Gandhi 1999, p. 56, pl. 3, fig. 125.

Valves $24.5 \mu \mathrm{m}$ long, $4.5 \mu \mathrm{m}$ broad; keel punctae 8-9 in $10 \mu \mathrm{m}$; striae 17 in $10 \mu \mathrm{m}$.

Distribution in Nepal: New record for Nepal.

23. Surirella tenera Greg. var. ambigua Gandhi (Fig. 23)

Gandhi 1957, p. 54, pl. 13, fig. 21; Gandhi 1999, p. 79, pl. 4, figs. 194-195.

Valves $89.5 \mu \mathrm{m}$ long, $30 \mu \mathrm{m}$ broad; costae 5 in $20 \mu \mathrm{m}$.

Distribution in Nepal: New record for Nepal.

\section{Results and Discussion}

In the present study, a total 23 algae have been reported from Betana wetland among which 6 taxa viz. Gomphonema constrictum Ehr. var capitata, Gomphonema intricatum Kütz.var. vibrio, Gomphonema parvulum (Kütz.) var. lagenula Hust., Rhopalodia gibba (Ehr.) O. Müll. var. ventricosa, Nitzschia amphibia Grun. and Surirella tenera Greg. var. ambigua Gandhi were the new records for Nepal. Diatoms were the most dominant algae, representing by 16 taxa whereas green algae were the least, representing by only one taxa i.e. Cosmarium maculatiforme. More green algae present in the samples were still unidentified. Among the taxa, the dominancy was found as follows Oscillatoria princeps $>$ Cymbella cymbiformis var. nonpunctata > Gomphonema sphaerophorum > Pinnularia braunii var. amphicephala > Lyngbya majuscula > Cosmarium maculatiforme > Melosira varians and so on. Fleshy gelatinous balls of Nostochopsis lobatus were found to be attached on the submerged walls of the outlet canal. Similarly, pure mucilaginous mass of Lyngbya species were found as floating on the edge of wetland. Further extensive algal exploration of the wetland periodically as well as seasonally and their relationship with water chemistry are essential and to be carried out in the future. 

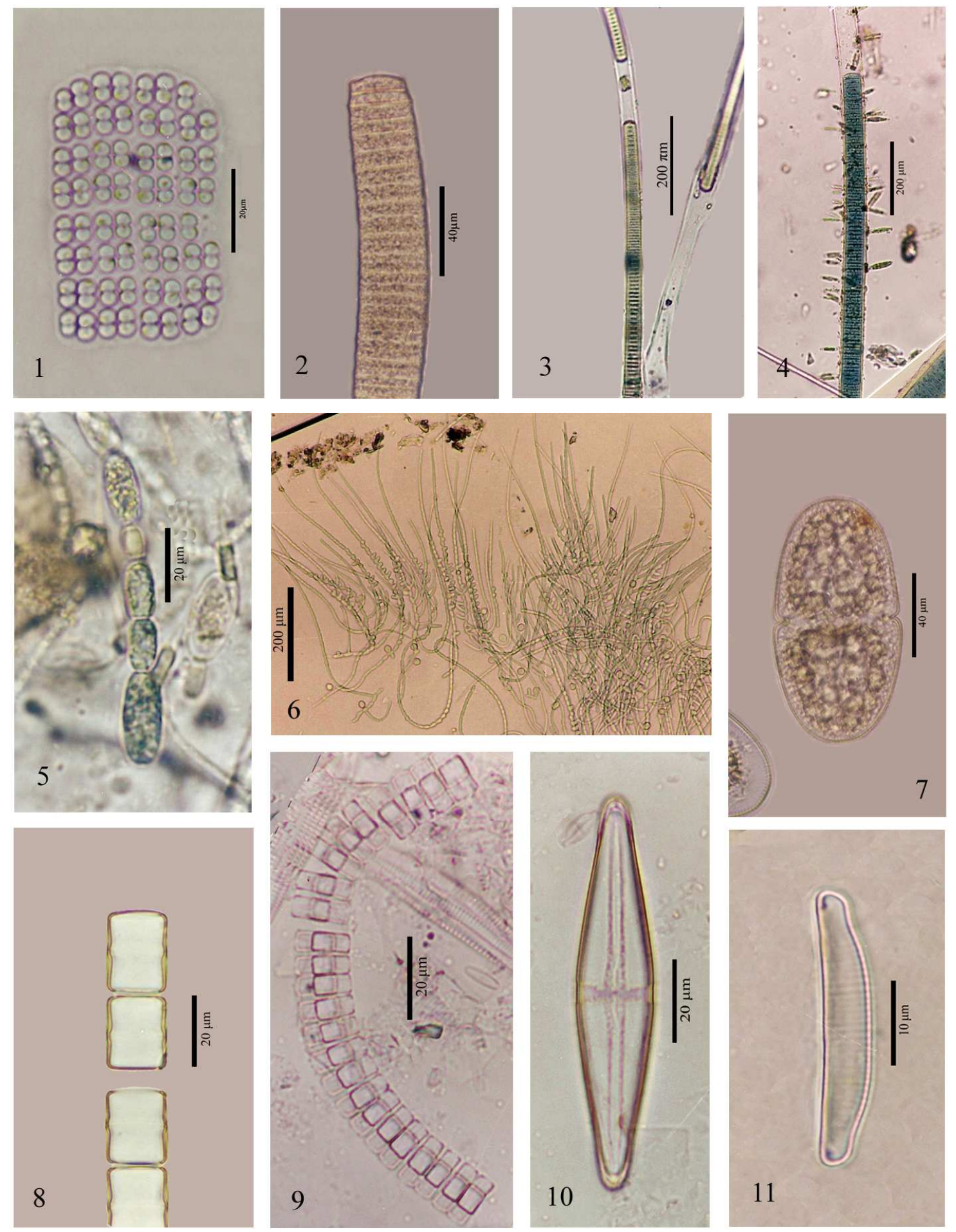

Figures 1. Merismopedia elegans 2. Oscillatoria princeps 3. Lyngbya birgei 4. Lyngbya majuscula 5. Anabaena iyengarii 6. Nostochopsis lobatus 7. Cosmarium maculatiforme 8. Melosira varians 9. Fragilaria construence var. construence 10. Stauroneis javanica 11. Eunotia tschirchiana. 

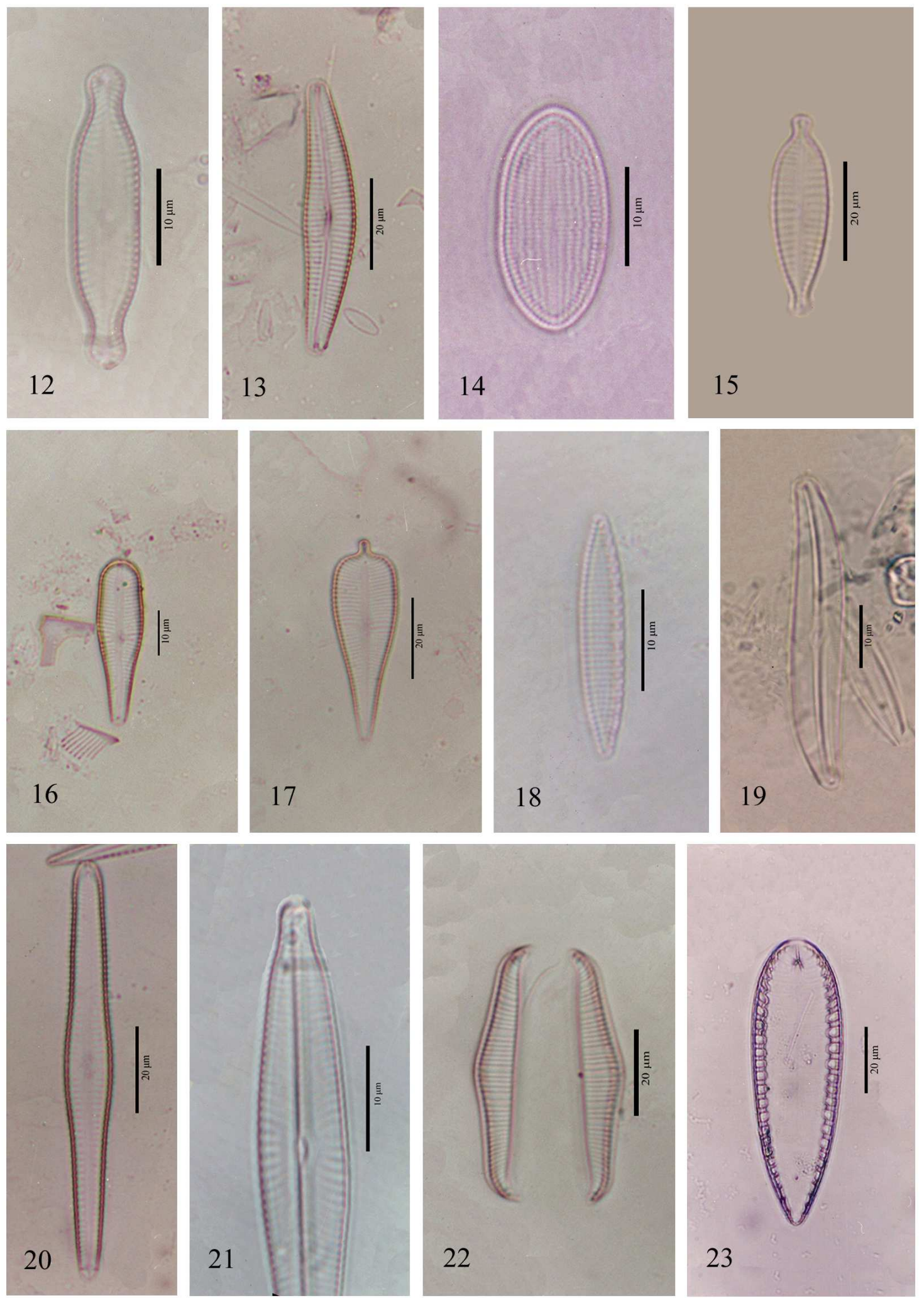

Figures 12. Pinnularia braunii var. amphicephala 13. Cymbella cymbiformis var. nonpunctata 14. Cocconeis placentula var. euglypta 15. Gomphonema sphaerophorum 16. Gomphonema cf parvulum var. lagenula 17. Gomphonema cf constrictum var capitata 18. Nitzschia amphibia 19. Gyrosigma scalproides 20. Gomphonema cf intricatum var. vibrio 21. Navicula viridula 22. Rhopalodia gibba var. ventricosa 23. Surirella tenera var. ambigua. 
The history of Nepalese phycology showed poor and sporadic explorations and have only countable reports in comparison to the neighbouring countries. Though, Nepal is rich in algal diversity due to its diverse climate and rich lotic and lentic habitats, this branch has given least priority from the beginning. Recently, as the world has focused on the modern algal nanotechnology, biotechnology, genetics, bio-fuel, super food, natural health medicines, climate change, bio-indicator, pollution control, bio-fertilizer etc., interest has been increasing on this micro-flora to some extent.

A complete record and database by extensive explorations throughout the country is essential and should be carry out soon and then the practice to sustainable use of algae by promoting its farming for agriculture, food, medicine etc. that uplift economy of the nation should be started. Betana pond would be an appropriate natural habitat for mass cultivation of algae in the future to supply the need of industrial production.

\section{Acknowledgement}

I would like to acknowledge the Head, Department of Botany, P.G. Campus, Biratnagar for laboratory facilities. Thanks also due to University Grants Commission (UGC), Nepal for financial assistance.

\section{References}

Aryal, S. \& P. Lacoul. 1996. Water quality and diversity of diatoms in Punyamati river, Nepal. Ecoprint 3(1): 45-49.

Carter, J.R. \& P. Denny. 1987. Fresh water algae of Sierra Leone IV. Bacillariophyceae: part (ii) diatoms from the coastal regions of the Southern Province. Nova Hedwigia 44(1-2): 229-275.

Das, S.N. \& B.N. Verma. 1996. Algal flroa of Chitwan and Nawalparasi districts of Nepal. Phykos 35(1-2): 119-127.

Desikachary, T.V. 1959. Cyanophyta. I.C.A.R. monograph on algae, New Delhi. 686 p.

Foged, N. 1980. Diatoms in Egypt. Nova Hedwigia 33(1-4): 629-675-707.

Foged, N. 1982. Diatoms in human tissue. Nova Hedwigia 36(2-4): 345-379.

Foged, N. 1986. Diatoms in Anholt, a Danish island in the Cattegat. Nova Hedwigia 42(24): 553-589.

Gandhi, H.P. 1959. Fresh water diatoms from Sagar in the Mysore state. J. Ind. Bot. Soc. 38(3): 305-331.

Gandhi, H.P. 1999. Fresh water diatom of cental Gujrat. B. Singh and M.P. Singh, Deharadun, India. $324 \mathrm{p}$.

Geitler, L. 1932. Cyanophyceae in Rabenhorst's Kryptogamen flora, Leipzig 14. 1196 p.

Habib, I. 1997. Algal flora from Mahendranagar, Nepal. J .Econ. and Taxon. Bot. (India) 21(1): 19-26.

Hadi, R.A.M., A.A. Al-saboonchi \& A.K.Y. Haroon. 1984. Diatoms of the Shatt al-Arab river, Iraq. Nova Hedwigia 39(3-4): 513-544-557.

Hirano, M. 1955. Fresh water algae. In: Fauna and flora of Nepal Himalaya (Ed. H. Kihara), Fauna and Flora Research Society, Kyoto University, Kyoto, Japan. pp. 542.

Hirano, M. 1963. Fresh water algae from the Nepal Himalaya, collected by a member of the Japanese Climbing Expedition. Contr. Biol. Lab., Kyoto Univ., Japan. 16: 1-23.

Hirano, M. 1984. Fresh water algae from East Nepal. Study reported of Baika Junior College 32: 197-215. 
Hustedt, F. 1938. Systematische und ökologische Unter suchungen über die Diatomeen flora von Java, Bali und Sumatra. Archiv f. Hydrobiol. Suppl. 15: 131-177, 187295, 293-506.

Hustedt, F. 1959. Die Kieselalgen Deutschlands, Österreichs Und der Schweiz, vol. 2. Koeltz Scientific Books, USA. 845 p.

Ishida, Y. (Ed.) 1986. Studies on distribution, adaptation and evolution of microorganisms in Nepal Himalayas (Second report). Kyoto, Japan. pp. 3-13.

Jha, S. \& A.N. Kargupta. 2001. Cyanobacterial flora of eastern Koshi basin, Nepal. Ecoprint 8(1): 37-43.

Jüttner, I., H. Rothfritz \& S.J. Ormerod. 1996. Diatoms as indicators of river quality in the Nepalese Middle hills with consideration of the effects of habitat-specific sampling. Freshwater Biology 36: 475-486.

Kobayasi, H. 1968. A survey of the fresh water diatoms in the vicinity of Tokyo. Jap. J. Bot. 20(1): 93-122.

Misra, P.K., S.K. Rai \& M.N. Srivastava. 2009. Fresh water diatoms from eastern Nepal-I. Indian Hydrobiology 12(1): 95-104.

Nurul Islam, A.K.M. 1970. Contributions to the knowledge of desmids of East Pakistan, Part I. Nova Hedwigia 20: 903-983.

Prasad, B.N. \& M.N. Srivastava. 1992. Fresh water algal flora of Andaman and Nicobar Islands, Vol. I. B. Singh and M.P. Singh, Dehra Dun, India. 369 p.

Prasad, B.N. 1996. Status of blue-green algal research in Nepal. In: International Symposium on Cyanobacterial Biotechnology, Sept.18-21, Bharathidasan University, Tiruchirapalli, India.

Rai, S.K. \& P.K. Misra. 2007. Spirogyra Link and Sirogonium Kutzing species: New to algal flora of Nepal. Ecoprint 14: 89-96.

Rai, S.K. \& P.K. Misra. 2008. On some desmids from Koshi Tappu Wildlife Reserve, Nepal. Ecoprint 15: 47-58.

Rai, S.K. \& P.K. Misra. 2010. Freshwater cyanophyceae from east Nepal. Bangladesh J. of Plant Taxonomy 17(2): 121-139.

Rai, S.K. \& R.K. Rai. 2005. Some bacillariophycean algae from Biratnagar, Nepal. Ecoprint 12: 71-76.

Rai, S.K. \& R.K. Rai. 2007. Some euglenophycean algae from Biratnagar, Nepal. Our Nature 5: 60-66.

Rai, S.K. 2005. Preliminary report of diatoms from Maipokhari lake, Ilam, Nepal. Our Nature 3(1): 26-30.

Rai, S.K. 2006. Taxonomic studies on some freshwater diatoms from the eastern Terai region, Nepal. Our Nature 4: 10-19.

Rai, S.K. 2009. Some chlorophycean algae from Maipokhari lake, Ilam, east Nepal. $J$. Nat. Hist. Mus, Nepal 24: 1-8.

Rai, S.K., B.R. Subba \& K.P. Limbu. 2008. Fresh water algae from running streams of Gajurmukhi VDC, Ilam, Nepal. Our Nature 6: 80-81.

Rai, S.K., R.K. Rai \& N. Poudel. 2008. Desmids from Bees-hazaar lake, Chitwan, Nepal. Our Nature 6: 58-66.

Rai, S.K., R.K. Rai \& S. Jha. 2010. Cyanobacteria of Nepal: A checklist with distribution. Our Nature 8: 336-354.

Rath, J. \& S.P. Adhikary. 2005. Algal flora of Chilka lake. Daya Publ. House, Delhi. 206 p.

Sahay, A.P., P.K. Das \& B.N. Verma. 1993. Studies on the algal flora of Nepal-II: Cyanophyceae and Euglenophyceae. Geophytology 23(1): 181-183.

Sant'anna, C.L. \& M.T.P. Azevedo. 1995. Oscillatoriaceae (cyanophyceae) from Sao Paulo state, Brazil. Nova Hedwigia 60(1-2): 19-58. 
Shrestha, B. \& J.D. Manandhar. 1983. Contribution to the algal flora of Kathmandu valley. J. Inst. Sci. Techn. (Nepal) 6:1-6.

Shrestha, B. 1982. The general survey of algae of Kathmandu valley. M.Sc. Thesis, Botany Department, Tribhuvan University, Kathmandu, Nepal.

Sinnu, N.A. \& L.E. Squires. 1985. Diatoms of the Damour river, Lebanon. Nova Hedwigia 41(1-4): 291-320-341.

Subba, B.R., M.R. Pandey, K.P. Limbu \& S.K. Rai. 2009. On some diatoms from Upper Mustang Trans-Himalaya Region, Nepal. Our Nature 7: 243-248.

Tiffany, L.H. \& M.E. Britton. 1952. The algae of Illinois. Hafner Publ. Co., New York. $407 \mathrm{p}$.

Turner, W.B. 1892. The fresh water algae of east India. Kongl. Sv. Vet. Akademiens Handlingar. 25(5): 1-187.

Upadhyaya, B.N. 1979. Two new records of Oscillatoria for Nepal. J. Nat. Hist. Mus. (Nepal) 3(3): 74-75.

Watanabe, M. \& J. Komarek. 1988. Blue-green algae from Kathmandu. In: Cryptogames of the Himalaya, Vol. 1, The Kathmandu valley. (Eds. M. Watanabe \& S.B. Malla), National Science Museum, Tsukuba, Japan. pp. 1-20. 